\title{
Immunity to cytopathic agents associated with Crohn's disease: a negative study
}

\author{
M CHIBA, L C McLAREN, AND R G STRICKLAND* \\ From the Division of Gastroenterology, Department of Medicine, University of New Mexico, \\ School of Medicine, Albuquerque, New Mexico, USA
}

SUMMARY Serum and peripheral blood lymphocytes from 10 patients with Crohn's disease and 10 healthy subjects were examined for immunological reactivity against chick embryo cell cultures displaying cytopathic effects after inoculation with $0.2 \mu$ filtrates prepared from Crohn's disease intestinal tissues. Although the assay systems (indirect immunofluorescence, lymphocyte transformation, and cytotoxicity) yielded positive results using well-characterised cytopathic viruses (mumps, measles), neither Crohn's disease nor healthy subjects showed immune reactivity to the chick embryo cell cultures inoculated with Crohn's disease intestinal tissues in any of the assay systems. These experiments provide evidence against the hypothesis that the in vitro cytopathic effect on chick embryo cell cultures produced by Crohn's disease intestinal filtrates are caused by a replicating virus or viruses.

Independent studies from three laboratories have shown that $0 \cdot 2 \mu$ filtrates of intestinal homogenates from patients with Crohn's disease cause transmissible cytopathic effects when inoculated into a variety of low passage fibroblast-like cell cultures. ${ }^{1-3}$ The frequency of this in vitro abnormality using Crohn's disease intestine $(80-90 \%)$ is significantly higher than that seen using disease control intestinal preparations $(25 \%){ }^{3}$

Early studies of the properties of this cytopathic effect suggested that it was produced by an RNAvirus. ${ }^{1-3}$ More recent work by Phillpotts et al., however, has questioned these findings ${ }^{4}$ and subsequently indicated that a soluble toxin(s) may be responsible for the in vitro cytopathic effect. ${ }^{56}$

In the present studies, we have used an immunological approach in attempting to clarify further the nature of the cytopathic effects induced by Crohn's disease tissue filtrate (CD-TF) in cell culture. We hypothesised that if these effects were viral in nature, viral antigens would be expressed in such cultures and host immune reactivity to these antigens should be demonstrable.

\footnotetext{
*Address for reprint requests: Dr R G Strickland, Division of Gastroenterology, Department of Medicine, University of New Mexico, School of Medicine, Albuquerque, New Mexico 87131, USA. Received for publication 19 October 1981
}

\begin{abstract}
Methods
PATIENTS

Venous blood was obtained from 10 patients with Crohn's disease (six women, four men) with a mean age 35 years (20-63 years) and 10 healthy adults (five women, five men) with a mean age of 29 years (23-39 years). Among the patients with Crohn's disease six had ileitis, two had ileocolitis, and two had colitis. Eight of the 10 patients had had the disease for more than five years. At the time of blood sampling four patients had active disease, five inactive, and one post-ileal resection two days before. Five patients were taking no drugs at the time of study. The remaining five patients were receiving sulphasalazine (one), sulphasalazine and prednisone (one), or prednisone (three). Serum was separated from an aliquot of the venous sample and stored at $-70^{\circ} \mathrm{C}$. The remainder of the sample was heparinised and used for lymphoid cell isolation.
\end{abstract}

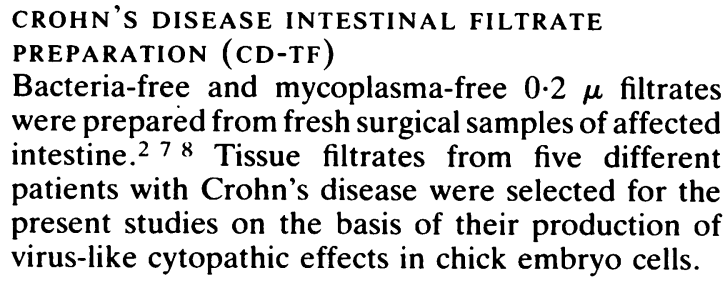

CROHN'S DISEASE INTESTINAL FILTRATE

PREPARATION (CD-TF)

Bacteria-free and mycoplasma-free $0.2 \mu$ filtrates were prepared from fresh surgical samples of affected patients with Crohn's disease were selected for the present studies on the basis of their production of 333 
TISSUE CULTURE, CD-TF INOCULATION, AND OBSERVATION OF CYTOPATHIC EFFECTS

As chick embryo cells were the most sensitive to the filtrate preparation, most of the immunological experiments were done using these culturtarget cells. Cell culture growth and maintenance media were the same as described by Gitnick et al. ${ }^{2}{ }^{7}$ Chick embryo cultures were established from 10-day-old fertile eggs (SPAFAS, Chicago, Ill). Passage two-chick embryo cells at $2 \times 10^{4 / 200 \mu l}$ growth medium were seeded into the wells of flat bottom microtitre plates (3040 Falcon, Oxnard, Ca). When monolayers were confluent, the medium was removed and the cells were incubated with $50 \mu$ l of the filtrate or $50 \mu$ l of Hanks balanced salt solution (HBSS) control for one hour at room temperature. Then $150 \mu \mathrm{l}$ of maintenance medium was added, and the monolayers were incubated at $37^{\circ} \mathrm{C}$ in humidified $5 \% \mathrm{CO}_{2}$ air. The monolayers were observed for the development of cytopathic effects after the inoculation and scored as follows: - cell appearance similar to control monolayer; + a focal cell detachment over a very small area; ++ definite rounding up cells, with or without cell detachment, over less than half of the well area +++ cell detachment over more than half of the well area. The same procedure for inoculation and scoring of cytopathic effects was observed in cultures used as positive virus controls. These included chick embryo cells inoculated with mumps virus (Enders strain) at a titre of $10^{5}-10^{6} \mathrm{TCID}_{50} / \mathrm{ml}$ and Vero cells (American Type Culture Collection, Rockville, Md), inoculated with measles virus (Edmonson strain, American Type Culture Collection) at a titre of $5 \times 10^{4} \mathrm{PFU} / \mathrm{ml}$.

\section{ISOLATION OF PERIPHERAL BLOOD LYMPHOID \\ CELLS}

Heparinised venous blood was diluted $1: 2$ with phosphate buffered saline and the lymphoid cells were isolated by Ficoll-Hypaque (Pharmacia, Fine Chemicals, Piscataway, NJ) density gradient centrifugation. ${ }^{9}$ Cell viability was over $95 \%$ by trypan blue exclusion, and the preparations contained $5-25 \%$ monocytes as judged by benzidine staining. ${ }^{10}$

\section{IMMUNOLOGICAL STUDIES}

Lymphocyte transformation

Lymphocyte transformation by glutaraldehyde-fixed monolayers Chick embryo monolayers displaying ++-+++ cytopathic effects after inoculation with the filtrate preparation or control monolayers were used as targets for lymphocyte transformation by a modification of the method of McFarland et al. ${ }^{11}$ Monolayers in flat bottom microtitre plates were fixed with $0.005 \%$ glutaraldehyde (Sigma, St. Louis, Mo) for 30 minutes at $4^{\circ} \mathrm{C}$ and washed three times with phosphate buffered saline. Then $2 \cdot 2 \times 10^{5}$ peripheral blood lymphoid cells in $150 \mu$ RPMI $1_{1640}{ }_{90} \mathrm{FCS}_{10}$ PS were added per well. After four days' incubation, the cells were pulsed for six hours with $0.36 \mu \mathrm{Ci}\left[{ }^{3} \mathrm{H}\right]$-thymidine $(6.7 \mathrm{ci} / \mathrm{mmol}, \mathrm{New}$ England Nuclear, Boston, Mass) per well, harvested with a multiple automated sample harvester, and counted. Uptakes of $\left[{ }^{3} \mathrm{H}\right]$-thymidine were expressed as mean cpm \pm one standard error as calculated from quadruplicate samples. Mumps virus (Enders) was used as a positive virus control in this experiment.

Lymphocyte transformation in suspension Crohn's disease intestinal filtrate preparations neat and at dilutions up to $1: 8$ were used as potential stimulants for $2.2 \times 10^{5}$ peripheral blood lymphoid cells in $150 \mu \mathrm{l}$ RPMI $1640_{90} \mathrm{FCS}_{10} \mathrm{PS}$ per well in round bottom type microtitre plates (Nunclon, Nuncatom, Roskilde, Denmark). Additional experiments were carried out using cell culture extracts as potential lymphocyte stimulants as described for human herpes virus infection. ${ }^{12} 13$ After the cytopathic effect was manifested, the monolayer was scraped off with a rubber policeman into $0.5 \mathrm{ml} \mathrm{Hanks} \mathrm{balanced} \mathrm{salt} \mathrm{solution}{ }^{12}$ or $0.043 \mathrm{M}$ glycine buffered saline ${ }^{13}$ and then subjected to freeze-thawing. Supernatants were collected after centrifugation at $600 \mathrm{~g}$ for 10 minutes. As a negative control, extracts of uninoculated monolayers were prepared in the same manner. Fifty microlitres of the supernatant were added to $2 \cdot 2 \times$ $10^{5}$ peripheral blood lymphocytes in $150 \mu$ l RPMI $1640{ }_{90} \mathrm{FCS}_{10} \mathrm{PS}$ in round bottom wells. After six days' incubation, the lymphocytes were pulsed with $\left[{ }^{3} \mathrm{H}\right]-$ thymidine and harvested as described for glutaraldehyde fixed monolayers.

\section{LYMPHOCYTE-MEDIATED CYTOTOXICITY}

Chick embryo cell monolayers grown in flat bottom microtitre wells-either uninoculated or inoculated with the Crohn's disease intestinal filtrate preparation-were incubated with medium containing 0.5 $\mu \mathrm{Ci}$ of $\left[{ }^{51} \mathrm{Cr}\right.$ ] $\mathrm{Na}_{2} \mathrm{CrO}_{4}(50-400 \mathrm{~m} \mathrm{Ci} / \mathrm{mg} \mathrm{Cr}$; Amersham Corp., Arlington Heights, Ill) for six hours, then washed three times with Eagle's minimal essential medium. $1 \times 10^{6}$ peripheral blood lymphocytes in $200 \mu \mathrm{l} \mathrm{RPMI}_{90} \mathrm{FCS}_{10} \mathrm{PS}$ were added to each well, and, after 16 hours' incubation, a $100 \mu$ l aliquot was carefully taken into a tube from each well without disturbing the monolayer in the bottom and replaced with $100 \mu$ l of diluted (1:10) Zaponin solution (Coulter Diagnostics Inc., Hialeah, Fla) to lyse the target cells. After an additional 24 hours' incubation, another $100 \mu \mathrm{l}$ aliquot was taken. These aliquots were counted in a well-type gamma scintillation counter (Packard, Downers Grove, Ill). The percent- 
age of ${ }^{51} \mathrm{Cr}$ release was calculated by the following method:

$$
\begin{aligned}
& \%^{51} \mathrm{Cr} \text { release }= \\
& \quad \frac{\text { released }{ }^{51} \mathrm{Cr} \text { in medium }}{\text { total releasable }{ }^{51} \mathrm{Cr}} \times 100=\frac{\mathrm{a}}{\mathrm{b}+1 / 2 \mathrm{a}} \times 100
\end{aligned}
$$

where $\mathrm{a}=\mathrm{cpm}$ obtained from the first aliquot of $100 \mu \mathrm{l}$

$$
\mathrm{b}=\mathrm{cpm} \text { obtained from the second aliquot of }
$$

This method, in which total releasable ${ }^{51} \mathrm{Cr}$ was obtained for each well tested, permits the calculation of an accurate $\%^{51} \mathrm{Cr}$ release. Spontaneous ${ }^{51} \mathrm{Cr}$ release distributed between $25 \%$ and $35 \%$. Spontaneous cell mediated cytotoxicity (SCMC) was obtained by the following calculation: $\operatorname{SCMC}(\%)=$ $\%^{51} \mathrm{Cr}$ release obtained from the incubation of peripheral blood lymphocytes and the inoculated or uninoculated monolayer-spontaneous release from the corresponding monolayer. ${ }^{14}$ Results were expressed as the mean of the quadruplicates \pm one standard error. Measles virus was used as a positive virus control in this experiment.

\section{INDIRECT IMMUNOFLUORESCENCE ANTIBODY TEST}

Chick embryo cells, passage 2, were seeded to Labtek Tissue culture chamber/slides (No. 4808, Naper- ville, Ill) and cultured until they were a confluent monolayer. The monolayers were inoculated with 50 $\mu l$ of the intestinal filtrate preparation, and, after one hour, $250 \mu \mathrm{l}$ of maintenance medium was added to the chamber. After the appearance of the cytopathic effect, the monolayers were washed with phosphate buffered saline, dried, then fixed with cold acetone for 10 to 15 minutes followed by washing with the saline. Sera from patients with Crohn's disease, healthy subjects, or persons in the acute (CF titre $1: 16$ ) or convalescent (CF titre 1:256) stages of measles were tested for antibody by the standard indirect method, using both FITC conjugated goat antihuman immunoglobulins (Antibody Incorporaated, Davis, Ca) or FITC conjugated antihuman 1 gM (Cappel Lab, Cochranville, Pa) as the second antibody.

\section{Results}

\section{LYMPHOCYTE TRANSFORMATION}

Lymphocyte transformation by glutaraldehyde-fixed monolayers (Table 1)

$\left[{ }^{3} \mathrm{H}\right]$-thymidine uptake by fixed monolayers alone was negligible $(<50 \mathrm{cpm})$. Peripheral blood lymphoid cells from all nine patients with Crohn's disease and 10 healthy controls showed the expected response to PHA. Those cells from two adults with a previous history of mumps showed substantial trans-

\begin{tabular}{|c|c|c|c|c|c|}
\hline Donor & Disease & Unstimulated & $\begin{array}{l}P H A \\
(2.5 \mu \mathrm{g} / \mathrm{ml})\end{array}$ & $\begin{array}{l}\text { Uninoculated } \\
\text { monolayer }\end{array}$ & $\begin{array}{l}\text { CD-TFinoculated } \\
\text { monolayer }\end{array}$ \\
\hline $\begin{array}{l}\text { BT } \\
\text { IN } \\
\text { MG } \\
\text { MN } \\
\text { AG } \\
\text { FR } \\
\text { CB } \\
\text { WM } \\
\text { JS } \\
\text { JE } \\
\text { ST } \\
\text { AN } \\
\text { MC } \\
\text { LZ } \\
\text { RO } \\
\text { DA } \\
\text { LO } \\
\text { LI } \\
\text { PA }\end{array}$ & $\begin{array}{l}\text { CD } \\
\text { CD } \\
C D \\
C D \\
C D \\
C D \\
C D \\
C D \\
\text { CD } \\
\text { Control } \\
\text { Control } \\
\text { Control } \\
\text { Control } \\
\text { Control } \\
\text { Control } \\
\text { Control } \\
\text { Control } \\
\text { Control } \\
\text { Control }\end{array}$ & $\begin{array}{c}596 \pm 135 \\
443 \pm 90 \\
2111 \pm 94 \\
1547 \pm 40 \\
763 \pm 62 \\
323 \pm 51 \\
604 \pm 126 \\
1024 \pm 52 \\
1173 \pm 89 \\
2304 \pm 331 \\
1185 \pm 73 \\
2329 \pm 411 \\
1123 \pm 97 \\
6279 \pm 201 \\
4398 \pm 718 \\
2320 \pm 187 \\
5693 \pm 1169 \\
1816 \pm 158 \\
6465 \pm 2278\end{array}$ & $\begin{array}{l}6396 \pm 267 \\
25080 \pm 1575 \\
33774 \pm 717 \\
44375 \pm 3767 \\
26168 \pm 2319 \\
21342 \pm 613 \\
21247 \pm 4709 \\
28190 \pm 868 \\
23230 \pm 1709 \\
14274 \pm 2276 \\
46587 \pm 3485 \\
16008 \pm 743 \\
23526 \pm 1062 \\
23135 \pm 1234 \\
47002 \pm 1291 \\
54130 \pm 5628 \\
75813 \pm 8127 \\
11639 \pm 456 \\
17840 \pm 1708\end{array}$ & $\begin{array}{c}391 \pm 78 \\
466 \pm 141 \\
1390 \pm 141 \\
1482 \pm 277 \\
999 \pm 51 \\
353 \pm 9 \\
1269 \pm 122 \\
954 \pm 46 \\
903 \pm 265 \\
2225 \pm 267 \\
909 \pm 105 \\
1939 \pm 180 \\
1161 \pm 61 \\
5924 \pm 632 \\
9247 \pm 829 \\
3024 \pm 400 \\
6280 \pm 850 \\
2294 \pm 72 \\
5411 \pm 889\end{array}$ & $\begin{array}{c}367 \pm 77 \\
387 \pm 24 \\
2034 \pm 149 \\
1597 \pm 328 \\
1235 \pm 31 \\
361 \pm 38 \\
1570 \pm 194 \\
1420 \pm 11 \\
1174 \pm 90 \\
2721 \pm 322 \\
1286 \pm 14 \\
2010 \pm 208 \\
1210 \pm 58 \\
6374 \pm 482 \\
12642 \pm 545 \\
2932 \pm 398 \\
8099 \pm 1353 \\
2451 \pm 328 \\
6131 \pm 532\end{array}$ \\
\hline & & & & & $\begin{array}{l}\text { Mumps virus } \\
\text { inoculated } \\
\text { monolayer }\end{array}$ \\
\hline LO & $\begin{array}{l}\text { Healthy adults } \\
\text { with history. } \\
\text { of mumps }\end{array}$ & $2932 \pm 516$ & $63012 \pm 5061$ & $6140 \pm 1032$ & $31138 \pm 5320$ \\
\hline OK & & $1873 \pm 201$ & $16549 \pm 1209$ & $1595 \pm 181$ & $4050 \pm 68$ \\
\hline
\end{tabular}
formation in response to the mumps inoculated fixed

Table 1 Peripheral blood lymphocyte transformation by fixed cell monolayers inoculated with Crohn's disease tissue filtrate $(C D-T F)$

Values indicate mean $\left[{ }^{3} \mathrm{H}\right]$-thymidine uptake $(\mathrm{CPM}) \pm \mathrm{SEM}$ of quadruplicate samples. 
monolayer showing ++ cytopathic effects when compared with uninoculated monolayers. By contrast, the peripheral blood lymphoid cells from the patients with Crohn's disease and from the healthy controls showed no response to the filtrate inoculated fixed monolayers showing equivalent cytopathic effect to that induced by mumps virus. Crohn's disease intestinal filtrate preparations from three different patients were used in these experiments, and each lymphocyte donor was tested against at least two different filtrate inoculated monolayers. Peripheral blood lymphocytes from two patients with Crohn's disease and four controls were harvested on the fourth, fifth, and sixth days of incubation with the cell monolayers, and again no response was observed.

Lymphocyte transformation by Crohn's disease tissue filtrate and cell culture extracts

This filtrate when used undiluted significantly inhibited $\left[{ }^{3} \mathrm{H}\right]$-thymidine uptake by the peripheral blood lymphocytes from four patients with Crohn's disease and four healthy subjects (Table 2). In four subjects tested, the inhibitory effect was substantially decreased by serial dilution of the filtrate (Table 2). In three subjects (one Crohn's disease, two controls), all five filtrates were tested. Spontaneous $\left[{ }^{3} \mathrm{H}\right]-$ thymidine uptake in these three individuals was uniformly inhibited by all five filtrates. This inhibitory effect of the Crohn's disease tissue filtrate was not eliminated by heat treatment $\left(65^{\circ} \mathrm{C}, 20\right.$ minutes) or by ultraviolet irradiation. The responses of four patients with Crohn's disease and one healthy control were not altered by incubation with GBS cell extracts derived from two filtrate inoculated cultures or to the same cell extracts without GBS treatment (Table 3).

\section{Lymphocyte-mediated cytotoxicity}

Peripheral blood lymphoid cells from 10 patients with Crohn's disease and nine healthy subjects were each tested against at least two monolayers inoculated with Crohn's disease tissue filtrates. The lymphoid cells from most donors showed some spontaneous cell mediated cytotoxicity over that due to spontaneous release. There was, however, no difference in this cytotoxicity in inoculated compared with uninoculated monolayers (Table 4). By contrast, using the same assay system, lymphoid cells from healthy subjects with a history of measles showed higher cytotoxicity against vero cells infected with measles virus than against uninfected vero cells (Table 4).

\section{Indirect immunofluorescence antibody test}

Ten sera from patients with Crohn's disease and 10 sera from healthy subjects were tested at a 1:10 dilution against monolayers of chick embryo cells inoculated with two different Crohn's disease tissue filtrates and showing +-+++ cytopathic effect. In both uninoculated and Crohn's disease tissue filtrate

Table 2 Peripheral blood lymphocyte transformation in response to Crohn's disease tissue filtrates (CD-TF)

\begin{tabular}{|c|c|c|c|c|c|c|c|}
\hline \multirow[t]{2}{*}{ Donor } & \multirow[t]{2}{*}{ Disease } & \multirow{2}{*}{$\begin{array}{l}\text { No. of CD-TF } \\
\text { tested }\end{array}$} & \multirow[t]{2}{*}{ Unstimulated } & \multicolumn{3}{|c|}{ Stimulated with $C D-T F$} & \multirow[b]{2}{*}{$1: 8$} \\
\hline & & & & Neat & $1: 2$ & $1: 4$ & \\
\hline $\begin{array}{l}\text { CB } \\
\text { IN } \\
\text { BT } \\
\text { GM } \\
\text { PA } \\
\text { MC } \\
\text { JE } \\
\text { ST }\end{array}$ & $\begin{array}{l}\text { CD } \\
C D \\
C D \\
C D \\
\text { Control } \\
\text { Control } \\
\text { Control } \\
\text { Control }\end{array}$ & $\begin{array}{l}2 \\
2 \\
1 \\
5 \\
5 \\
5 \\
2 \\
2\end{array}$ & $\begin{array}{c}152 \pm 21 \\
1176 \pm 180 \\
283 \pm 143 \\
286 \pm 79 \\
420 \pm 51 \\
343 \pm 53 \\
1030 \pm 219 \\
2040 \pm 264\end{array}$ & $\begin{array}{c}62 \pm 6 \\
287 \pm 118 \\
79 \pm 18 \\
39 \pm 9 \\
41 \pm 19 \\
47 \pm 15 \\
488 \pm 72 \\
942 \pm 192\end{array}$ & $\begin{array}{l}\text { NT } \\
\text { NT } \\
\text { NT } \\
104 \pm 7 \\
67 \pm 8 \\
91 \pm 13 \\
\text { NT } \\
\text { NT }\end{array}$ & $\begin{array}{l}\text { NT } \\
\text { NT } \\
\text { NT } \\
160 \pm 22 \\
155 \pm 30 \\
153 \pm 14 \\
584 \pm 301 \\
\text { NT }\end{array}$ & $\begin{array}{l}\text { NT } \\
\text { NT } \\
\text { NT } \\
299 \pm 67 \\
287 \pm 82 \\
273 \pm 46 \\
730 \pm 194 \\
\text { NT }\end{array}$ \\
\hline \multicolumn{8}{|c|}{$\begin{array}{l}\text { NT: not tested. } \\
\text { Values indicate mean }\left[{ }^{3} \mathrm{H}\right] \text {-thymidine uptake }(\mathrm{CPM}) \pm \mathrm{SEM} \text { of quadruplicate samples. }\end{array}$} \\
\hline \multicolumn{8}{|c|}{$\begin{array}{l}\text { Table } 3 \text { Peripheral blood lymphocyte transformation in response to } G B S \text { and non-GBS extracts of cell cultures inoculated } \\
\text { with Crohn's disease tissue filtrates (CD-TF) }\end{array}$} \\
\hline \multirow[t]{2}{*}{ Donor } & \multirow[t]{2}{*}{ Disease } & \multirow[t]{2}{*}{ Unstimulate } & \multirow[t]{2}{*}{ Extract } & \multicolumn{3}{|c|}{ Tissue culture extract stimulated } & \multirow[b]{2}{*}{$\begin{array}{l}\text { Inoculated } \\
\text { with } C D-T F^{2}\end{array}$} \\
\hline & & & & \multicolumn{2}{|c|}{ Uninoculated } & $\begin{array}{l}\text { Inoculated } \\
\text { with } C D-T F^{\prime}\end{array}$ & \\
\hline $\begin{array}{l}\text { MN } \\
\text { MG } \\
\text { MC } \\
\text { AG } \\
\text { FR }\end{array}$ & $\begin{array}{l}\text { CD } \\
\text { CD } \\
\text { Control } \\
\text { CD } \\
\text { CD }\end{array}$ & $\begin{array}{c}448 \pm 122 \\
487 \pm 79 \\
1092 \pm 41 \\
1223 \pm 204 \\
2003 \pm 217\end{array}$ & $\begin{array}{l}\text { GBS } \\
\text { GBS } \\
\text { GBS } \\
\text { Non-GBS } \\
\text { Non-GBS }\end{array}$ & \multicolumn{2}{|c|}{$\begin{array}{c}332 \pm 71 \\
445 \pm 41 \\
1663 \pm 244 \\
1190 \pm 370 \\
2542 \pm 241\end{array}$} & $\begin{array}{c}326 \pm 29 \\
379 \pm 10 \\
2096 \pm 336 \\
1228 \pm 358 \\
2162 \pm 309\end{array}$ & $\begin{array}{c}356 \pm 32 \\
417 \pm 91 \\
2210 \pm 86 \\
1471 \pm 309 \\
2183 \pm 496\end{array}$ \\
\hline
\end{tabular}

Values indicate mean $\left[{ }^{3} \mathrm{H}\right]$-thymidine uptake $(\mathrm{CPM}) \pm \mathrm{SEM}$ of quadruplicate samples. 
Table 4 Peripheral blood lymphocyte (PBL) cytotoxicity $(S C M C)$ for ${ }^{5 I}$ Cr-labelled chick embryo cell monolayers uninoculated or inoculated with Crohn's disease tissue filtrates (CD-TF)

\begin{tabular}{|c|c|c|c|c|}
\hline Donor & Disease & Uninoculated & Inoculated (CD-TFI) & Inoculated (CD-TF2) \\
\hline $\begin{array}{l}\text { GM } \\
\text { WM } \\
\text { IN } \\
\text { BT } \\
\text { MG } \\
\text { MN } \\
\text { AG } \\
\text { FR } \\
\text { CB } \\
\text { JS }\end{array}$ & $\begin{array}{l}C D \\
C D \\
C D \\
C D \\
C D \\
C D \\
C D \\
C D \\
C D \\
C D\end{array}$ & $\begin{array}{r}4 \cdot 2 \\
16 \cdot 2 \\
39 \cdot 6 \\
5 \cdot 9 \\
2 \cdot 5 \\
2 \cdot 1 \\
1 \cdot 4 \\
0 \cdot 6 \\
0 \\
0 \cdot 2\end{array}$ & $\begin{array}{c}2.2 \\
19.5 \\
28.9 \\
5.9 \\
0 \\
1.7 \\
2.7 \\
0.1 \\
1 \cdot 0 \\
0.7\end{array}$ & $\begin{array}{c}8 \cdot 3 \\
15 \cdot 5 \\
29.3 \\
2.6 \\
0 \\
\text { NT } \\
1.9 \\
0 \cdot 9 \\
0 \cdot 8 \\
0\end{array}$ \\
\hline \multirow[t]{2}{*}{$\begin{array}{l}\text { MC } \\
\text { PA } \\
\text { ST } \\
\text { JE } \\
\text { AN } \\
\text { LZ } \\
\text { RO } \\
\text { DA } \\
\text { LO }\end{array}$} & $\begin{array}{l}\text { Control } \\
\text { Control } \\
\text { Control } \\
\text { Control } \\
\text { Control } \\
\text { Control } \\
\text { Control } \\
\text { Control } \\
\text { Control }\end{array}$ & $\begin{array}{c}6 \cdot 5 \\
4 \cdot 1 \\
2 \cdot 6 \\
15 \cdot 0 \\
7 \cdot 3 \\
0 \\
0 \\
6 \cdot 4 \\
8 \cdot 7\end{array}$ & $\begin{array}{l}0 \\
3 \cdot 0 \\
0 \\
8 \cdot 3 \\
5 \cdot 8 \\
2 \cdot 0 \\
0 \\
4 \cdot 3 \\
6 \cdot 3\end{array}$ & $\begin{array}{l}3 \cdot 7 \\
6 \cdot 5 \\
0 \\
8 \cdot 4 \\
5 \cdot 1 \\
0 \\
0 \cdot 7 \\
1 \cdot 6 \\
6 \cdot 8\end{array}$ \\
\hline & & $\begin{array}{l}\text { Uninoculated } \\
\text { vero cells }\end{array}$ & $\begin{array}{l}\text { Measles virus inoculated } \\
\text { vero cells }\end{array}$ & \\
\hline MS & $\begin{array}{l}\text { Healthy adults with } \\
\text { history of measles }\end{array}$ & $4 \cdot 3$ & $15 \cdot 7$ & \\
\hline MC & & $5 \cdot 7$ & $17 \cdot 6$ & \\
\hline
\end{tabular}

$\% \mathrm{SCMC}=\%{ }_{51}^{51} \mathrm{Cr}$ release from monolayer incubated with $\mathrm{PBL}$ - spontaneous.

${ }^{51} \mathrm{Cr}$ release from monolayer alone.

inoculated monolayers all sera caused faint, diffuse cytoplasmic staining. Neither an increase in the intensity of the fluorescent staining nor an increase in the number of stained cells was seen in monolayers inoculated with the filtrate. Serial serum dilutions $(1: 5-1: 60)$, the use of goat anti-IgM as second antibody or the use of another cell culture system susceptible to the Crohn's disease filtrate (WI-38) did not result in significant fluorescent reactions. By contrast, in the virus control experiment, sera (1:10-1:60 dilutions) from two patients with measles in either the acute or convalescent stage showed bright staining against measles infected vero cells and no staining against uninfected control monolayers.

\section{Discussion}

Previous studies of the in vitro cytopathic effect of Crohn's disease intestinal filtrates have suggested that it is caused by an RNA-virus associated with the diseased bowel of such patients. ${ }^{1} 2{ }^{3}$ Thus, the cytopathic effect is transmissible in cell culture, unaffected by heat, ether, acid, or IUdr and virus-like particles have been described in cultures undergoing this effect. ${ }^{1}{ }^{2}{ }^{3}$ If this effect is caused by a cytopathic virus, then, by analogy with other known virus systems, host immunity to the agent should be readily demonstrable. Thus in the present studies we have used several established techniques in attempting to show cellular and humoral immunity to putative virus(es) present in cell cultures undergoing cytopathic effect after inoculation with Crohn's disease intestinal filtrates.

Glutaraldehyde-fixed cell monolayers displaying cytotoxicity after inoculation with mumps, vaccinia, and measles viruses have been shown to elicit lymphocyte transformation, using peripheral blood lymphoid cells from subjects previously sensitised to these viruses. ${ }^{11}$ In the present study we have confirmed this finding using mumps virus infected fixed cell monolayers. Using identical cell monolayers undergoing cytopathic effect in response to inoculation with Crohn's disease intestinal filtrates, however, no transformation of lymphoid cells from patients with Crohn's disease or healthy controls was observed (Table 1).

We also attempted to elicit lymphocyte transformation in suspension using the Crohn's disease intestinal filtrate and cell extracts from cultures undergoing cytopathic effect after inoculation with this filtrate. The use of these extracts was predicted on evidence indicating that cell membraneassociated viral antigens are of key importance in the production of in vitro lymphocyte transformation. ${ }^{14}{ }^{15}$ Such extracts have been successfully used to demonstrate lymphocyte transformation in human herpes virus infection. ${ }^{12} 13$ In the present study, the undiluted filtrate actually caused consistent inhibi- 
tion of lymphocyte transformation, and the filtrate inoculated cell extracts yielded no response either stimulatory or inhibitory (Tables 2,3 ).

The in vivo significance of in vitro lymphocytemediated cytotoxicity against virus infected target cells remains uncertain. Nevertheless, this in vitro assay has been shown to reflect lymphocyte (T-cell, $\mathrm{N}-\mathrm{K}$ cell, or both) reactivity in several established viral infections in man. ${ }^{14} 1617$ Using peripheral blood lymphoid cells from subjects exposed to measles, we have confirmed the presence of enhanced cytotoxicity against cell cultures infected with measles virus. By contrast, using these cells from control subjects or patients with Crohn's disease in a similar assay system incorporating cell cultures inoculated with Crohn's disease intestinal filtrates, no enhanced cytotoxicity was demonstrable (Table 4). As these experiments used xenogeneic target cells, the major function measured by these assays was probably that of $\mathrm{N}-\mathrm{K}$ activity, rather than T-cell cytotoxicity.

Our previous attempts to detect antibody to the putative viral agents in Crohn's disease necessitated serum neutralisation of the cytopathic effect. ${ }^{3}$ These studies showed inhibition only at low serum dilutions, and no differences were observed between sera from patients with Crohn's disease and normal sera. ${ }^{3}$ The present results using immunofluorescence also indicate the absence of apparent antibody activity in sera from patients with Crohn's disease or normal sera towards antigens expressed in cell cultures undergoing the cytopathic effect after inoculation with Crohn's disease intestinal filtrates. These findings are in agreement with those recently reported by Phillpotts et al. ${ }^{5} 6$

Thus, using established methods for detecting cellular and humoral immunity to known cytopathic viruses in culture, we have been able to show such reactivity to the proposed agents associated with Crohn's disease previously implicated in causing in vitro cytopathic effects. The number of donors studied ( 10 with Crohn's disease, 10 controls) was not large, but the consistency of the findings makes subject selection an unlikely explanation for the negative results. Could the findings be attributable to a more generalised depression of cellular immune function in Crohn's disease? Previous studies of cellular immunity in Crohn's disease have been in sharp conflict with regard to the presence or absence of T-cell deficiency ${ }^{18}$ Moreover, in the present study there was no significant difference in PHA responses between control or Crohn's disease PBL. Recently, N-K activity has been reported to be reduced in Crohn's disease,$^{19}$ and possibly our negative findings using cytotoxicity could reflect deficient $\mathrm{N}-\mathrm{K}$ function. This possibility would not, however, explain the negative results obtained using transformation assays.

In conclusion, we suggest that the results of the present study raise considerable doubt about the proposed viral causation of the in vitro cytopathic effect induced by Crohn's disease tissue filtrates. Very recent studies by Phillpotts et al. 6 and McLaren et al. ${ }^{20}$ also provide evidence against this proposal. These workers have shown that many of the properties of the cytotoxicity induced by these filtrates are more consistent with a tissue associated toxic effect. Indeed, the inhibitory effect of Crohn's disease tissue filtrates on lymphocyte function observed in the present study may also represent such a toxic effect.

We thank Elizabeth Dow for technical assistance and Mr R Steece of New Mexico State Health Laboratory for providing the mumps virus used in this study. This work was supported by USPHS Research Grant AM27354.

\section{References}

1 Aronson MD, Phillips CA, Beeken WL, Forsyth BR. Isolation and characterisation of a viral agent from intestinal tissue of patients with Crohn's disease and other intestinal disorders. Prog Med Virol 1975; 21:165-76.

2 Gitnick GL, Arthur MN, Shibata I. Cultivation of viral agents from Crohn's disease: A new sensitive system. Lancet 1976; ii:215-7.

3 Strickland RG, Mclaren LC. Studies of the in vitro cytopathic effect of inflammatory bowel disease tissue preparations. In: Pena AS, Weterman IT, Booth CC, Strober W, eds. Developments in gastroenterology. The Hague: Martinus Nijhoff, 1982:246-51.

4 Phillpotts RJ, Hermon-Taylor J, Brooke BN. Virus isolation studies in Crohn's disease: a negative report. Gut 1979; 20: 1057-62.

5 Phillpotts RJ, Hermon-Taylor J, Teich NM, Brooke BN. A search for persistent virus infection in Crohn's disease. Gut 1980; 21:202-7.

6 Phillpotts RJ, Hermon-Taylor J, Brooke BN. Evidence against the involvement of conventional viruses in Crohn's disease. In: Pena AS, Weterman IT, Booth CC, Strober W, eds. Developments in gastroenterology. The Hague: Martinus Nijhoff, 1981:252-5.

7 Gitnick, Rosen VJ. Arthur MH, Hertweck, SA. Evidence for the isolation of a new virus from ulcerative colitis patients: comparison with virus derived from Crohn's disease. Digestive Disease and Science 1979; 24: 609-19.

8 Hayflick L. Tissue culture and mycoplasmas. Texas Rep Biol Med 1965; 23:285-303.

9 Aiuti F, Cerottini JC, Coombes RA, et al. Special technical report. Identification, enumeration and isolation of B and T lymphocytes from human peripheral blood. Scand J Immunol 1974; 3:521-32.

10 Kaplow LS. Simplified myeloperoxidase stain using benzidine dihydrochloride, Blood 1965; 26:215-9. 
11 McFarland HF, McFarlin DE: Cellular immune response to measles, mumps and vaccinia viruses in multiple sclerosis. Ann Neurol 1979; 6:101-6.

12 Corey L, Reeves WC, Holmes KK. Cellular immune response in genital herpes simplex virus infection. $N$ Engl J Med 1978; 299:986-91.

13 Zaia JA, Leary PL, Levin MJ. Specificity of the blastogenic response of human mononuclear cells to herpes virus antigens. Infect Immunol 1978; 20:646-51.

14 Bellanti JA, Meters SM, Rola-Pleszczynski M. Assays of cell-mediated immunity to viruses. In: Rose NR, Friedman $\mathrm{H}$, eds. Manual of clinical immunology. Washington, DC: American Society for Microbiology, 1976: $155-65$.

15 Ruckdeschel JC, Mardiney MP. The demonstration of cell-associated immunity to viruses. In vitro lymphocyte responsiveness to varicella-zoster antigen. J Immunol Methods 1976; 13:131-43.

16 Anderson T, Stejskal V, Harfast B. An in vitro method for study of human lymphocyte cytotoxicity against mumps-virus-infected target cells. J Immunol 1975; 114:237-43.

17 Steele RW, Hensen SA, Vincent MM, Fuccillo DA, Bellanti JA: A ${ }^{51} \mathrm{Cr}$ microassay technique for cellmediated immunity to viruses. J Immunol 1973; 110: $1502-10$.

18 Strickland RG, Sachar DB. The immunology of inflammatory bowel disease. In: Jerzy Glass JB, ed. Progress in gastroenterology. Vol 3. New York:Grune and Stratton, 1977:821-38.

19 Auer IO, Ziemer E, Sommer H. Immune status in Crohn's disease $v$ decreased in vitro natural killer cell activity in peripheral blood. Clin Exp Immunol 1980; 42:41-9.

20 McLaren L, Bartlett J, Gitnick G. IBD Research Group. Infectious agents in inflammatory bowel disease (IBD): Collaborative studies. (Abstract.) Gastroenterology 1981; 80:1228. 